\title{
Profil keganasan saluran cerna di RSUP Prof. Dr. R. D. Kandou Manado tahun 2014-2015
}

\author{
${ }^{1}$ Def R. M. Kabo \\ ${ }^{2}$ Bradley J. Waleleng \\ ${ }^{2}$ Harlinda Haroen
}

\author{
${ }^{1}$ Kandidat Skripsi Fakultas Kedokteran Universitas Sam Ratulangi Manado \\ ${ }^{2}$ Bagian/SMF Ilmu Penyakit Dalam Fakultas Kedokteran \\ Universitas Sam Ratulangi Manado \\ Email: defkabo@yahoo.com
}

\begin{abstract}
Gastrointestinal cancer refers to malignant condition of the gastrointestinal tract and accessory organ of digestion including esophagus, stomach, biliary system, pancreas, small intestine, large intestine, rectum, and anus. In 2012, WHO reported that the incidence of colorectal cancer was 1.361 , gastric cancer was 0.952 , and esophageal cancer was 0.456 per 100,000 population. This study was aimed to identify the profile of gastrointestinal malignancy in Prof. Dr. R. D. Kandou Hospital Manado in 2014-2015. This was a retrospective descriptive study based on the data of the Installation of Medical Record of Prof. Dr. R. D. Kandou Hospital Manado of gastrointestinal malignancy cases. There were 39 patients as samples. The majority of cases were male (25 patients; 64.1\%), age group 6069 years (17 patients; 43.6\%), had colorectal cancer (35 patients; 89.7\%), and adenocarcinoma as the most common type (23 patients; $58.9 \%$ ). The most common treatment was chemotherapy (14 patients; 35. 9\%). Conclusion: In this study, most cases were males aged 60-69 years.
\end{abstract}

Keywords: malignancy, cancer, gastrointestinal.

\begin{abstract}
Abstrak: Kanker saluran cerna mengacu pada kondisi keganasan pada saluran pencernaan dan organ aksesori pencernaan, termasuk esofagus, lambung, sistem empedu, pankreas, usus kecil, usus besar, rektum dan anus. Studi oleh WHO tahun 2012 melaoprkan insiden terjadinya kanker kolorektal 1,361, kanker perut/gaster 0,952, dan kanker esofagus 0,456 per 100.000 penduduk. Penelitian ini bertujuan untuk mengetahui profil keganasan saluran cerna di RSUP Prof. dr. R. D. Kandou Manado Tahun 2014-2015. Jenis penelitian ialah deskriptif retrospektif berdasarkan data di Bagian Instalasi Rekam Medik RSUP Prof. dr. R. D. Kandou Manado Tahun 2014-2015 yang menderita keganasan saluran cerna. Sampel penelitian berjumlah 39 kasus. Mayoritas kasus ialah jenis kelamin laki-laki yaitu 25 pasien $(64,1 \%)$ dan kelompok usia 60-69 tahun yaitu 17 orang $(43,6 \%)$, menderita kanker kolorektal yaitu 35 kasus $(89,7 \%)$, adenokarsinoma merupakan jenis kanker tersering yaitu 23 pasien $(58,9 \%)$. Tatalaksana yang sering dilakukan ialah kemoterapi sebanyak 14 pasien $(35,9 \%)$. Simpulan: Pada penelitian ini terbanyak pada jenis kelamin laki-laki dan kelompok usia6069 tahun.
\end{abstract}

Kata kunci: keganasan, kaker, saluran cerna.

Kanker atau keganasan adalah sekelompok penyakit yang ditandai dengan pertumbuhan yang tidak terkendali dan penyebaran sel-sel abnormal. Jika penyebaran tidak terkontrol, dapat mengakibatkan kematian. ${ }^{1}$ Kanker adalah salah satu masalah kesehatan di dunia dan merupakan penyakit dengan tingkat 
mortalitas kedua tertinggi setelah kardiovaskular. $^{2}$

Seiring dengan pertumbuhan dan pertambahan usia penduduk, pada tahun 2030 diperkirakan akan mucul 21,7 juta kasus kanker baru dan 13 juta kematian yang diakibatkan oleh kanker. ${ }^{3}$ Menurut International Agency for Research on Cancer (IARC), diperkirakan terdapat 14,1 juta kasus kanker baru pada tahun 2012 di seluruh dunia, 8 juta terjadi di negaranegara ekonomi berkembang, yang mengandung sekitar $82 \%$ dari populasi dunia. $^{4}$

Pada tahun 2012, perkiraan secara global insiden kanker saluran cerna kolorektal pada pria menduduki kanker dengan insidensi terbanyak keempat sebanyak 10,1\%, disusul oleh kanker perut/gaster sebanyak $8,5 \%$ dan esofagus $4,4 \%$. Pada wanita, kanker kolorektal merupakan kanker dengan insiden ketiga terbesar sebanyak 9,2\%. Diikuti kanker perut/gaster $4,8 \%$ pada urutan keenam. ${ }^{5}$

Kanker pencernaan mengacu pada kondisi keganasan pada saluran pencernaan dan organ aksesori pencernaan, termasuk esofagus, lambung, sistem empedu, pankreas, usus kecil, usus besar, rektum dan anus. ${ }^{6}$

Studi oleh WHO tahun 2012, prevalensi kanker kolorektum 3,544, kanker perut/gaster 1,538 , dan esofagus 0,464 per 100.000. Sedangkan insiden terjadinya kanker kolorektum 1,361, kanker perut/gaster 0,952, dan kanker esofagus 0,456 per 100.000 penduduk. $^{7}$ Kanker kolorektal merupakan kanker paling umum ketiga pada laki-laki dan yang kedua pada perrempuan. Di seluruh dunia, diperkirakan 1,4 juta kasus kanker kolorektal terjadi pada tahun $2012{ }^{4}$

Prevalensi kanker di Indonesia sebesar 1,4 per 1000 penduduk. Provinsi DI Yogyakarta merupakan provinsi dengan prevalensi kanker tertinggi yaitu $4,1 \%$, disusul oleh Jawa Tengah 2,1 \% dan Bali $2 \%$ sedangkan Sulawesi Utara memiliki prevalensi kanker sebanyak $1,7 \%{ }^{8}$

Kota Manado belum memiliki angka pasti mengenai jumlah kasus keganasan saluran cerna, sehingga penulis merasa perlu untuk melakukan penelitian mengenai profil keganasan saluran cerna di RSUP Prof. Dr. R. D. Kandou Manado. Diharapkan penelitian ini dapat menjadi profil keganasan saluran cerna di Sulawesi Utara karena RSUP Prof. Dr. R. D. Kandou Manado merupakan rumah sakit pusat rujukan medis Provinsi Sulawesi Utara.

\section{METODE PENELITIAN}

Jenis penelitian ini ialah deskriptif retrospektif berdasarkan data sekunder di Bagian Instalasi Rekam Medik RSUP Prof. dr. R. D. Kandou Manado tahun 2014-2015 yang menderita keganasan saluran cerna.

Populasi dalam penelitian ini ialah seluruh pasien keganasan saluran cerna di RSUP Prof. Dr. R. D. Kandou Manado Tahun 2014-2015. Sampel penelitian ini merupakan pasien rawat inap yang didiagnosis mengalami keganasan saluran cerna di RSUP Prof. Dr. R. D. Kandou Manado tahun 2014-2015 yang termasuk dalam kriteria inklusi.

Variabel penelitian antara lain jenis kelamin, usia, lokasi keganasan saluran cerna, jenis sel kanker, riwayat penyakit keluarga yang menderita keganasan saluran cerna, stadium klinis, dan tatalaksana.

Data penelitian diolah secara manual dan menggunakan aplikasi Microsoft Excel dan disajikan dalam bentuk tulisan dan tabel distribusi frekuensi.

\section{HASIL PENELITIAN}

Berdasarkan data yang diambil dari Instalasi Rekam Medik RSUP Prof. dr. R. D. Kandou, jumlah keganasan saluran cerna tahun 2014-2015 sebanyak 83 pasien; 39 diantaranya masuk dalam kriteria inklusi.

Diagram batang pada Gambar 1 menunjukkan bahwa dari 39 data keganasan saluran cerna yang menjadi sampel penelitian terdapat 25 sampel $(64,1 \%)$ berjenis kelamin laki-laki dan 14 sampel $(35,9 \%)$ berjenis kelamin perempuan. 


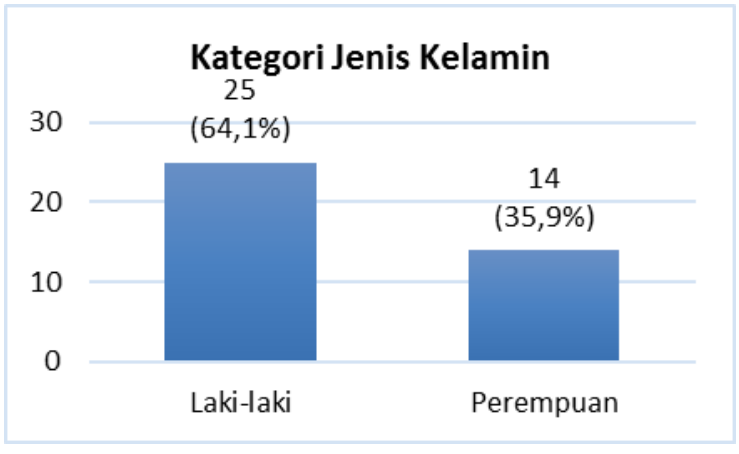

Gambar 1. Distribusi Sampel Berdasarkan Jenis Kelamin

Distribusi sampel berdasarkan usia dalam penelitian ini dibagi dalam 5 kelompok usia. Diagram batang pada Gambar 2 menunjukkan bahwa dari 39 data yang menjadi sampel penelitian, proporsi tertinggi pada kelompok usia 60-69 tahun sebanyak 17 sampel $(43,6 \%)$, diikuti kelompok usia 40-49 sebanyak 10 sampel (25,6\%), kelompok usia 50-59 sebanyak 8 sampel (20,6\%), dan kelompok usia 30-39 dan $>70$ masing-masing sebanyak 2 sampel $(5,1 \%)$.

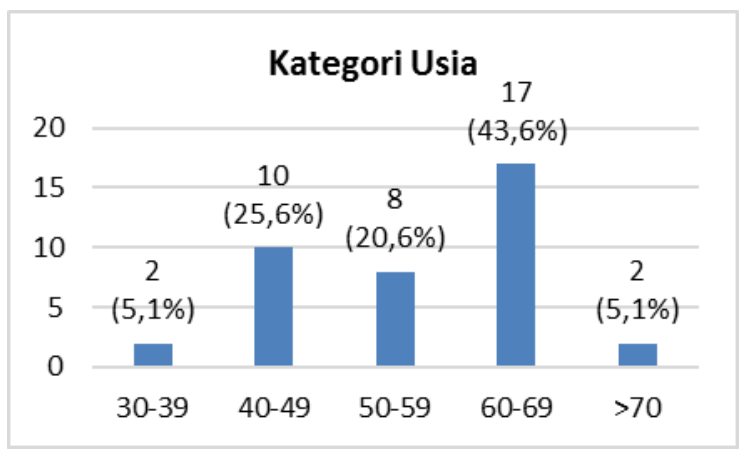

Gambar 2. Distribusi Sampel Berdasarkan Usia

Berdasarkan Gambar 3 dapat dilihat bahwa proporsi tertinggi pada lokasi kolorektal sebanyak 35 sampel $(89,7 \%)$, diikuti oleh anus 2 sampel $(5,1 \%)$, duodenum dan esofagus masing-masing 1 sampel $(2,6 \%)$, dan tidak terdapat sampel pada lokasi gaster.

Berdasarkan Gambar 4 didapatkan distribusi jenis sel kanker terbanyak adalah adenokarsinoma sebanyak 23 sampel $(58,9 \%)$. Terdapat 13 sampel $(33,3 \%)$ yang masuk dalam kriteria inklusi walaupun tidak terdapat data jenis sel kanker berdasarkan hasil pemeriksaan penunjang, dan terdapat jenis sel kanker small cell carcinoid, leiomiosarkoma, dan limfoma masing-masing sebanyak 1 sampel $(2,6 \%)$.

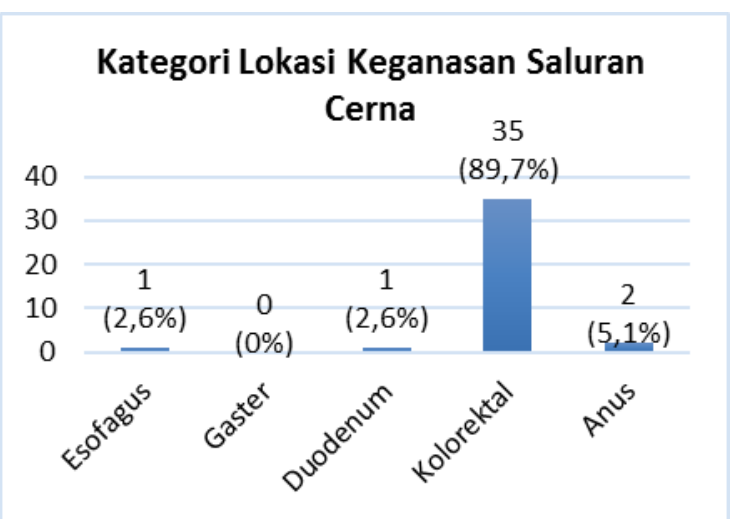

Gambar 3. Distribusi Sampel Berdasarkan Lokasi Saluran Cerna

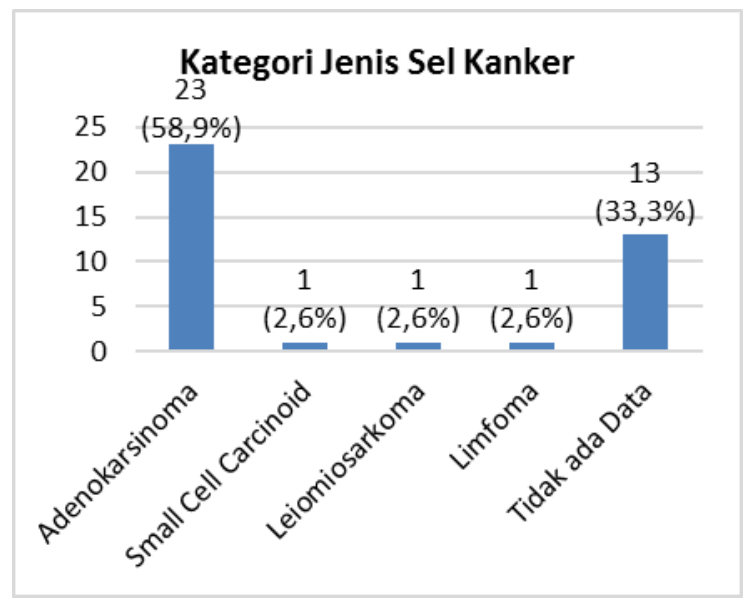

Gambar 4. Distribusi Sampel Berdasarkan Jenis Sel Kanker

Pada data rekam medik pasien keganasan saluran cerna tidak dicantumkan stadium klinis kanker sesuai dengan lokasi keganasan saluran cerna sehingga variabel ini tidak dapat dipergunakan untuk mendapatkan hasil dan kesimpulan penelitian.

Berdasarkan hasil penelitian, tidak didapatkan data pada rekam medik pasien keganasan saluran cerna yang menunjukkan ada tidaknya riwayat penyakit keluarga yang menderita keganasan saluran cerna. Maka variabel ini tidak dapat memberikan hasil dan kesimpulan penelitian.

Berdasarkan hasil penelitian, dari 39 data keganasan saluran cerna yang menjadi 
sampel penelitian dilakukan tindakan tatalaksana, terdapat 14 sampel $(35,9 \%)$ dilakukan kemoterapi, 11 sampel $(28,2 \%)$ dilakukan operasi, 10 sampel $(25,6 \%)$ dilakukan operasi dan kemoterapi, dan sebanyak 4 sampel $(10,3 \%)$ tidak dilakukan operasi ataupun kemoterapi.

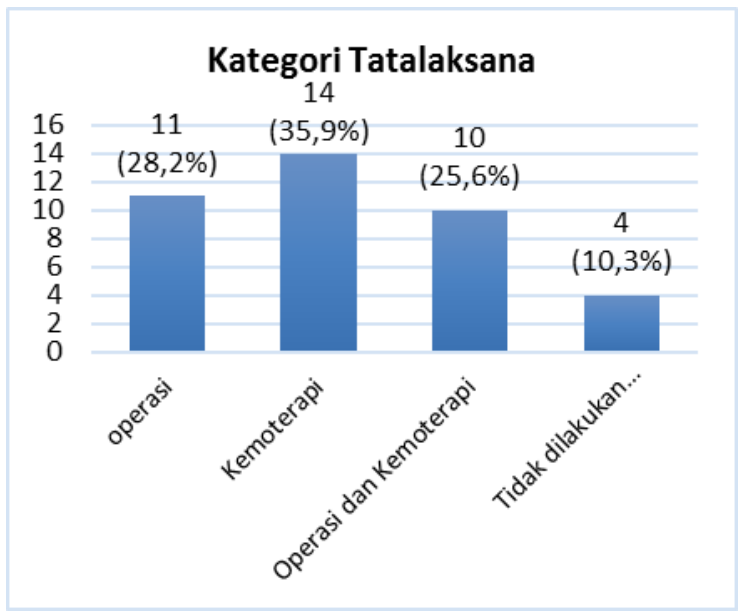

Gambar 5. Distribusi Sampel Berdasarkan Tatalaksana

\section{BAHASAN}

Berdasarkan data yang diperoleh, didapatkan proporsi tertinggi pasien keganasan saluran cerna berdasarkan jenis kelamin adalah laki-laki sebesar $64,1 \%$. Sedangkan proporsi yang terendah adalah perempuan sebesar $35,9 \%$. Hasil penelitian ini berbeda dengan hasil penelitian Nainggolan (2008) berdasarkan data Riset Kesehatan Dasar (RISKESDAS) yang menemukan penderita kanker saluran cerna berjenis kelamin perempuan $(69,4 \%)$ lebih banyak dibandingkan jenis kelamin lakilaki $(30,6 \%){ }^{9}$

Berdasarkan kelompok umur diperoleh data proporsi tertinggi pasien keganasan saluran cerna adalah kelompok umur 60-69 tahun yang berjumlah 17 pasien $(43,6 \%)$. Hasil penelitian ini sesuai dengan hasil penelitian Nainggolan (2008) yaitu kasus yang paling banyak terdapat pada kelompok umur lebih dari 60 tahun dengan jumlah kasus sebanyak 73 kasus dari 248 kasus $(29,4 \%){ }^{9}$

Berdasarkan lokasi keganasan saluran cerna hasil penelitian menunjukkan kolorektal merupakan lokasi terbanyak sebesar $89,7 \%$ dan lokasi terendah pada gaster yang tidak memiliki sampel. Hasil penelitian ini sesuai dengan penelitian yang dilakukan oleh American Cancer Society (2016) mendapatkan kolon merupakan kanker saluran cerna terbanyak dibandingkan dengan wilayah yang lain, sebanyak 95.270. Diikuti oleh rektum sebanyak 39.220 pasien di Amerika. ${ }^{10}$

Berdasarkan jenis sel kanker didapatkan proporsi tertinggi yaitu adenokarsinoma sebanyak 58,9\%. Hasil penelitian ini tidak membagi jenis sel kanker sesuai dengan lokasi keganasan saluran cerna. Namun pada penelitian lain, jenis sel kanker dipisahkan sesuai dengan lokasi keganasan saluran cerna. Pada esofagus, karsinoma sel skuamous merupakan tumor/kanker esofagus yang sering dijumpai, yaitu sekitar $60 \%$ dari keseluruhan karsinoma esofagus, dan biasanya bersifat fatal dalam kurang dari 5 tahun. ${ }^{11}$ Pada gaster, jenis sel kanker tertinggi adalah adenokarsinoma sebanyak 90-95\%. ${ }^{12}$ Pada lokasi usus halus jenis histologis yang paling umum pada keganasan usus halus dan mewakili 25$50 \%$ dari seluruh kanker usus halus adalah adenokarsinoma. $^{13}$ Adenokarsinoma juga merupakan jenis sel kanker paling banyak di kolorektal dengan persentase $98 \%$. $^{14}$

Berdasarkan data rekam medik, tidak didapatkan data mengenai distribusi sampel berdasarkan stadium klinis keganasan saluran cerna di RSUP Prof. dr. R. D. Kandou Manado. Proses staging dilakukan setelah mendapatkan anamnesis dan pemeriksaan fisik, dilengkapi dengan pendekatan laboratorium. Menurut The American Joint Committee on Cancer (AJCC) staging tumor esofagus menggunakan sistem tumor-nodemetastase (TNM), begitu juga dengan lokasi tumor/kanker lainnya. ${ }^{11}$

Pada kanker kolorektal, kelangsungan hidup sangat tergantung pada stadium penyakit saat diagnosis yang mengacu pada stadium kanker dalam tubuh. Selain itu, stadium klinis dapat menentukan pilihan pengobatan dan memiliki pengaruh yang kuat pada panjang kelangsungan hidup. 
Kisaran ketahanan hidup 5 tahun kanker kolorektal adalah $90 \%$ untuk kanker yang terdeteksi pada tahap lokal; $70 \%$ untuk regional; $10 \%$ pada kanker yang telah bermetastasis. Secara umum, semakin dini terdiagnosis, semakin tinggi kesempatan untuk bertahan hidup. Pada penelitian yang lain menyebutkan pada kanker usus besar dan rektum, 39,4\% didiagnosis pada stadium lokal. Kelangsungan hidup 5 tahun pada kanker kolon dan rektum adalah $90,1 \% .^{15,16}$

Berdasarkan data rekam medik, tidak didapatkan data mengenai riwayat penyakit keluarga yang menderita keganasan saluran cerna di RSUP Prof. dr. R. D. Kandou Manado. Pada kolorektal dapat timbul melalui interaksi kompleks antara faktor genetik mendominasi yang lainnya pada kasus sindrom herediter seperti Familial Adenonatorus Polyposis (FAP) dan Hereditary Nonpolyposis Colorectal Cancer (HNPC). ${ }^{17}$

Pada penelitian sebelumnya mengatakan bahwa sampai dengan $20 \%$ dari orang yang menderita kanker kolorektal memiliki anggota keluarga lainnya yang telah saling berhubungan. Orang dengan riwayat kanker kolorektal atau polip adenomatosa dalam satu atau lebih saudara tingkat pertama berada pada peningkatan risiko. Hal ini lebih tinggi pada orang dengan riwayat keluarga yang kuat, seperti riwayat kanker kolorektal atau polip adenomatous dalam tingkat pertama yang relatif lebih muda dari usia 60; atau riwayat kanker kolorektal atau polip adenomatosa dalam dua atau lebih saudara tingkat pertama pada setiap umur sekitar 25 tahun. Penyebab terjadi peningkatan risiko tidak jelas, tetapi kemungkinan karena gen yang diwariskan, faktor lingkungan bersama, atau kombinasi dari ini. ${ }^{15,18}$

Berdasarkan tatalaksana yang dikategorikan sebagai operasi, kemoterapi, serta operasi dan kemoterapi, didapatkan kemoterapi merupakan tertinggi sebanyak $35,9 \%$. Hasil penelitian ini tidak membagi tatalaksana sesuai dengan lokasi keganasan saluran cerna. Tatalaksana dilakukan berdasarkan kesehatan, keinginan pasien, dan yang paling utama stadium klinis sesuai dengan lokasi keganasan saluran cerna. Pada kolorektal stadium I, tidak direkomendasikan dilaksanakan kemoterapi. Operasi merupakan pengobatan definitif. Jika kanker ditemukan pada tahap yang sangat awal, akan dilakukan kolonoskopi. Peran kemoterapi pada stadium II kanker usus besar masih bisa diperdebatkan, dan biasanya tidak ditawarkan kecuali memiliki faktor risiko seperti tumor T4 atau kelenjar getah bening tidak memadai untuk identifikasi sampling. Pada stadium III dan IV kanker kolorektal, kemoterapi merupakan bagian integral dari pengobatan. ${ }^{19}$

Pengobatan karsinoma esofagus dipertimbangkan meliputi gambaran histologi, gradasi, dan staging tumor; jenis kelamin dan kesehatan secara umum penderita, situasi sosial penderita, dan akses pelayanan kesehatan, ketersediaan pemeriksaan diagnosis khusus, terapi, dan fasilitas mendukung. Hal yang paling penting adalah kemauan dan kesediaan penderita. $^{20}$

Jika kanker esofagus didiagnosis saat masih dalam tahap awal, tatalaksana bedah dengan maksud kuratif dapat dilaksanakan. Beberapa tumor kecil yang hanya melibatkan mukosa atau lapisan esofagus dapat dihilangkan dengan Endoscopic Mucosal Resection (EMR). Jika tidak, pembedahan kuratif lesi tahap awal mungkin memerlukan penghapusan seluruh atau sebagian dari esofagus (esophagectomy). ${ }^{21,22}$

Tidak seperti tahap kanker lambung dini di mana reseksi bedah adalah satusatunya modalitas kuratif, pengobatan kanker lambung pada tahap lanjut sulit dan kombinasi kemoterapi bedah dan adjuvant atau radiasi diperlukan untuk hasil yang lebih baik. ${ }^{20}$

\section{SIMPULAN}

Berdasarkan hasil penelitian dapat disimpulkan bahwa mayoritas kasus keganasan saluran cerna ialah jenis kelamin laki-laki dan kelompok usia 60-69 tahun dengan lokasi terbanyak pada kolorektal 
dan jenis adenokarsinoma. Tatalaksana yang paling sering dilakukan ialah kemoterapi.

\section{SARAN}

1. Bagi pihak tenaga medis RSUP Prof. dr. R. D. Kandou Manado agar lebih memperhatikan kelengkapan status pasien khususnya pada penelitian ini mengenai riwayat penyakit keluarga dan stadium klinis keganasan saluran cerna sesuai dengan lokasi yang tidak dicantumkan.

2. Bagi pihak rumah sakit sebaiknya dilakukan perbaikan dalam pencatatan data sekunder agar data-data yang ingin diperoleh lebih lengkap sehingga penelitian dapat berjalan lancar. Selain itu, diharapkan lebih memperhatikan pengarsipan data sekunder agar data dapat diperoleh dengan mudah dan tidak ada data pasien yang tidak ditemukan.

3. Bagi petugas kesehatan lainnya untuk melakukan penelitian yang lebih lanjut mengenai tumor/kanker saluran cerna, mengingat kurangnya sumber data dan informasi di Indonesia.

\section{DAFTAR PUSTAKA}

1. World health organization. Cancer. 2016. [cited Aug 27 2016]. Available from URL: http://www.who.int/cancer/en/

2. Boyle P, Levin B. World Cancer Report 2008. International Agency for Research on Cancer. WHO. 2008;5761.

3. GLOBOCAN 2012. Cancer incidence and mortality worldwide. 2012 [cited 2016 Aug 28]. Available from: http://globocan.iarc.fr.

4. Global cancer facts \& figures $3^{\text {rd }}$ ed. American cancer society. 2015 [cited 2016 Aug 27]. Available from URL: http://www.cancer.org/acs/groups/con tent/@ research/documents/document/ acspc-044738.pdf

5. GLOBOCAN 2012: Estimated cancer incidence, mortality and prevalence worldwide in 2012. International agency for research on cancer WHO. 2012 [cited 28 Aug 2016]. Available from URL: http://globocan.iarc.fr/Pages/fact_she ets_population.aspx

6. Yamada T, Alpers DH. Textbook of gastroenterology. $5^{\text {th }}$ ed. Chichester, West Sussex: Blackwell Pub. 2009. p.603-1028.

7. World cancer factsheets. Cancer research UK. January 2014 [cited Aug 25 2016]. Available from URL: http://publications.cancerresearchuk.o rg/downloads/Product/CS_REPORT_ WORLD.pdf

8. Departemen Kesehatan RI. Riset kesehatan dasar (Riskesdas). Jakarta: Departemen kesehatan RI;2013.

9. Nainggolan $D$, Maria $S$, Marice $S$. Fakror-faktor berhubungan dengan tumor/kanker saluran cerna berdasarkan survey kesehatan nasional. 2009;59:510-7.

10. American society. Cancer facts \& figures 2016. 2016 [cited 2016 Nov 15]. Available from: http://www.cancer.org/acs/groups/con tent/@research/documents/document/ acspc-044738.pdf

11. Arsana PI, Wibawa IDN. Seorang penderita dengan karsinoma sel skuamus esofagus. 2011;11:48-56.

12. Fan D, Wu K. Adenocarcinoma (gastric cancer and miscellaneous malignancy). In: Hauser SC, Pardi DS, Poterucha JJ, editors. Mayo clinic gastroenterology and hepatology board review. $3^{\text {rd }}$ ed. Canada: Mayo clinic scientific press and informa healthcare USA. 2008. p.77-96.

13. Somasundar PS. Malignant neoplasms of the small intestine. Medscape reference. 2015;1-5.

14. Radiopaedia. Colorectal carcinoma. 2014 Sep 2013 [cited 2015 Nov 15]. Available from: https://radiopaedia.org/articles/colore ctal-carcinoma

15. Haggar F, Boushey R. Colorectal cancer epidemiology: incidence, mortality, survival, and risk factors. Clin colon rectal surg. 2009;22(4):191-7.

16. National cancer institute. SEER stat facts sheets: colon and rectum cancer. 2013 [cited 2016 Nov 15]. Available from: http://seer.cancer.gov/statfacts/html/c olorect.html

17. Abdullah M. Tumor kolorektal. Dalam: 
Setiati S, Alwi I, Sudoyo AW, Simadibrata M, Setiyohadi B, Syam AF, editor. Edisi ke 6. Jakarta. InternaPublishing; 2014. h.375-80.

18. Boardman LA, Morlan BW, Rabe KG, Petersen M, Lindor N, Nigon S, et al. Colorectal cancer risks in relatives of young-onset cases: is risk the same across all first-degree relatives?. Clin Gastroenterol

Hepatol. 2007;5(10):1195-8.

19. Cunningham D, Atkin $W$, Lenz HT, Lynch HT, Minsky B, Nordlinger B, et al. colorectal cancer. Lancet. 2010;375(9719):1030-47.

20. Saghier A, Kabanja J, Afreen S, Sagar
M. Gastric cancer: environmental risk factor, treatment and prevention. Carcionogenesis \& mutagenesis. 2013:1-11.

21. Fernandez-Esparach G, Calderon A, Pena J, Tasende J, Esteban J, Gimeno-Garcia A, et al. Endoscopic Submucosal dissection. 2014;46(4):361-70.

22. Sun F, Yuan P, Chen T, Hu J. Efficacy and complication of endoscopic submucosal dissection superficial esophageal carcinoma: a systematic reviews and meta-analysis. 2014:978. 